\title{
Handling Abstraction in Chemistry with Animation
}

\author{
Chici Yuliana Nadi, \\ Sebelas Maret University, Surakarta, \\ Indonesia, \\ chiciyuli@gmail.com
}

\author{
Deny Tri Ardianto, \\ Sebelas Maret University, Surakarta, \\ Indonesia \\ denytri@staff.uns.ac.id
}

\author{
Akhmad Arif Mussadad \\ Sebelas Maret University, Surakarta, \\ Indonesia \\ arif_musaddad_fkip@yahoo.co.id
}

\begin{abstract}
Field of chemistry exists to fulfill the question of nature in which every explanation could only be achieved by expanding the scope of exploration to the micro or even sub-atomic scale. That tendency makes chemistry has an abstract characteristic, mostly because we know that human cannot perceive the atomic world empirically in their daily lives. Misconceptions frequently come up as a result of this abstraction, especially in the classroom condition. 2D animation video could give more precise image about that submicroscopic things which always dynamically move, such as the sub-atomic movement and atomic bonding. Research and development refer to developing design by Stephen M. Alessi and Stanley R. Trollip that was specific for developing media. 2D animation video product would, then, be uploaded to YouTube site, completed by its subtitle on open source license by Creative Common (CC), so it could be accessed and used by everyone.
\end{abstract}

Keywords : animation, chemistry, submicroscopic, learning media, YouTube

\section{INTRODUCTION}

Learning Chemistry for SHS students is a phasing unified material system of learning. To learn the higher level of material, one has to experience and apprehend the basic material. The lack of basic concept understanding would affect the understanding of the next materials. Mental representation is greatly affected by the prior knowledge [1]. Basic material such as Atomic Structure, Periodic Table of Elements, and Chemical Bonding are taught in the beginning as a basic for every other chemical concept [2]. The problem is that those three basic concepts easily bring misconceptions owing to their abstract characteristic. Misconception, in fact, is not only felt by students [3] but also teachers [4]. It is indicated by the uncomprehending of material, uncertainty and hesitantly to understand, knowing unreasoningly, and knowing just a particular or uncompleted concept [4]. An abstracting skill of students could be analyzed by their ability to describe or to make analogy of abstract concept and to create visual images from abstract microscopic events [5].

Teacher has an important role in the learning design [6][7]. In the designing process, learning phase is arranged by way it could be a guidance to achieve the prospective goal setting. In the field of Chemistry, those learning phases are intimately related to modeling and visualization. Model is representation of object, event, process, or system [8]. Modeling is the way to convey a theory built by scientists in their process of proving their theorem, such as mathematical equations (formulas), laws, and images (as like atomic or molecular model). Submicroscopic representative level is deeply connected to modeling. Still picture has its significant drawback which is its incapability of explaining moving characteristic of things it modeled. By considering Chemistry as a field dominated by abstraction (and by considering the incapability of still picture), then, its learning process should be upgraded by using multimedia products, such as games, videos, and simulation. Simulations can go some way to helping the worksheet mentality to be discouraged [9]. Yet, games and simulation development requires a lot of time and complicated programming codes. Hence, videos could be a good alternative media development that is most possible and applicable for teacher. Animation Video is a pictorial presentation that has become the most prominent feature of technology-based learning environment [10]. Animation is an image that changes over time [11].

In this new era of digitalization, everything should be as practical as possible, so that education should be. Teachers should face this broad and fast current of technology, as a recent trend which gives them a lot of works to do. It is related to teacher's roles as learning source, facilitator, manager, demonstrator, counselor, motivator, and learning evaluator [12]. Researcher analyzes teachers' need for chemistry multimedia learning, and makes first draft of chemistry animation video development. First draft could be used as a reference for teachers who want to make animation video but do not have a required skill to develop animation work.

\section{METHOD}

This study uses Alessi \& Trollip's research and development design (2001) as an alternative for developing animation video product. Research begins by fore-study which is done by surveying 15 Chemistry teachers who have an experience to teach Chemistry in grade X SHS, as research subjects. This beginning process requires quantitative descriptive design. Respondents have different durations of teaching experiences and teach in different cities in Indonesia. 


\section{RESULT AND DISCUSSION}

A. Chemical Bonding Material Analysis: The Problem of Abstraction

Analysis is done toward abstractive characteristic of Chemical Bonding material. Figure. 1 and Figure. 2 would show the difficulty to learn chemistry and difficulty faced by teacher to deliver the materials found by this analysis. Then, it is followed by data presentation about alternated solutional suggestion offered by teachers for handling the abstractive Chemistry.

Difficulty for reasoning $(73,39 \%)$ becomes the students' main difficulty for learning Chemical Bonding material. Reasoning is defined by process of logical thinking. Logical thinking process is closely related to every perceivable things or everything which could be conceived mindfully.

"Things are seldom what they seem" [9]. Before the development of science, people would be hard to accept that everything is compiled by atom, that are mostly $(99.99 \%$ of it is) an empty space [13]. This kind of logic would be hard to be perceived, because everything that we thought as tangible/solid material would be no more real, or just a compilation of empty spaces. That would be harder to deliver this logic to students who are just in their 15-18 years old. Piaget's cognitive development theory defining those ages (15-18) as phase of formal operational in which students should have capacity of abstractive principals [14] seems not applicable in this case. It shows that qualified prior knowledge would grant access to a proper discursive access supporting reasoning, in which this important thing seems to be left behind. That is because reasoning is a mingled process starting from sense-making, conjecturing, convincing, reflecting, and generalizing [15].

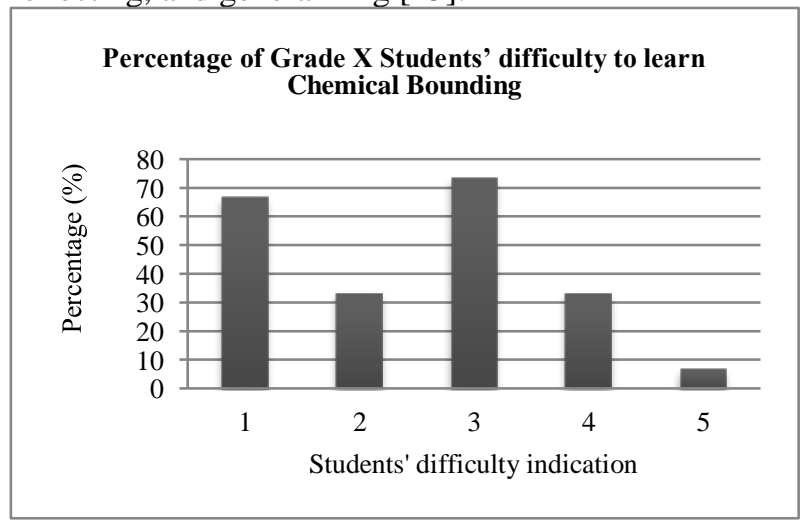

Figure. 1. Percentage of Grade X Students' difficulty to learn Chemical Bonding Note (Figure. 1):

$1=$ Difficulty for imagining $4=$ Difficulty for relating it within reality

$2=$ Difficulty for memorizing $5=$ No learning benefit

$3=$ Difficulty for reasoning

Students' failure for attaining the meaning seems to affect the lack of students understanding of Chemistry. Firstly because they do not have a perceiving experience, that becomes an integral reason of the difficulty for imagining $(66,70 \%)$. Secondly is about the logical knowledge that is hard to be accepted by human common-sense. It is showed by the difficulty for relating it within reality $(33,30 \%)$. Those five difficulties for learning Chemical Bonding are the characteristic of abstractive knowledge. It is as same as teachers' difficulty to teach Chemical Bonding material, which is the difficulty to attract students for imagining (53, $30 \%$ ), that can be seen in Figure. 2 .

Analogy could be a solution when we could not find any real example in our daily life. Many of the concepts of science don't present themselves for selective observations, so the best that can be done is analogy [9]. Thus makes both difficulty of finding real example and difficulty of finding analogy, getting same percentage, which is $20 \%$.

Here some solutions offered by teachers to solve the abstractive Chemical Bonding material's problem:

G1-Memberi ilustrasi terkait kehidupan sehari-hari(Giving an illustration related to daily life).

G2-Menggunakan animasi yang ditampilkan di depan kelas. Sehingga siswa mendapat gambaran yang jelas.(Using animation showed in the front of the class, so students could have a clear image).

G3-Memancing siswa terus bertanya jika belum memahami, dan menjelaskan dengan cara yang mudah dipahami siswa hingga siswa mengerti. (Attracting students' curiosity by offering them to ask whenever they think they do not quite understand and then reexplaining the materials within the easiest way they could possibly understand).

G4-Mengkaitkan materi dengan contoh real dalam kehidupan sehari-hari.(Relating materials to the real example in our daily life).

G5-Sebisa mungkin membantu anak dalam belajar.

(Helping students as much as we can do).

G6-Membuat (media pebelajaran) baru. (Making a new learning media)

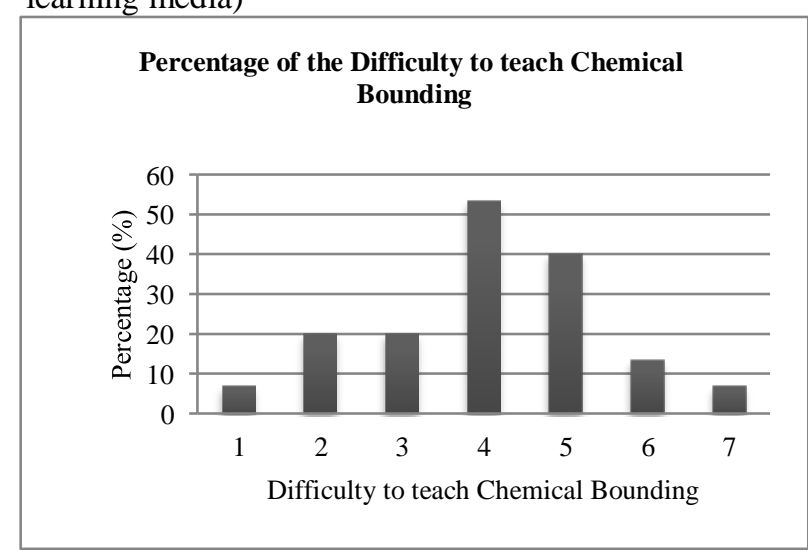

Figure. 2. Percentage of the Difficulty to teach Chemical Bonding Note:

$1=$ None $5=$ Finding proper learning media

$2=$ Finding analogy $6=$ Sticking on the benefit of learning

3 = Finding real example $7=\mathrm{A}$ lot of deviated law of Chemistry

4 = Asking students to imagine

G7-Dalam hal kesulitan membayangkan dan penalaran (ikatan ion dan kovalen), menggunakan bantuan sifat periodik unsur dan kaidah Oktet. Dalam hal sulit 
mengkaitkan dengan kenyataan, menggunakan bantuan perbedaan data sifat fisika antara senyawa ion dengan senyawa kovalen. (In the case of difficulty of imagining and reasoning-for ion \& covalent, we could use Periodic Table of Element and the rule of Octet. In the case of difficulty for relating to reality, we could use Physical characteristic data between ion compound and covalent compound).

G8-Dengan lagu kimia. (Using Chemistry song)

G9-Memberikan tugas kelompok. (Giving group assignment)

G10-Banyak latihan dan memberi contoh. (Giving more practices and examples)

G11-Memberi kaitan dengan kehidupan sehari-hari.

(Making a correlation with daily life)

G12-Dengan memanfaatkan media audiovisual. (Using audio-visual media)

G13-Siswa harus seotran hafalan unsur-unsur Sistem Periodik Unsur (SPU) karena dasar dalam belajar ikatan kimia menurut saya adalah SPU. (Assigning students to memorize Periodic Table of Elements).

G14-Dengan memvisualisasikan semudah mungkin. (Using simple visualization)

G15-Dengan molymod dari plastisin. (Using molymod by plastisin).

When teachers were asked to give a solution to face problems of teaching Chemical Bonding, some teachers answer completely as like what was done by G7. Some teachers give same advice to correlate materials with an example which is drawn from daily life (G1, G4, G11). Advice to use animation in the learning of Chemical Bonding comes from G2, G8, G12, G14, and G15, but most teachers find difficulty to find a proper learning media (40\%). It means teachers face a problem to find animation in the domain of Chemical Bonding. It is supported by visiting to the biggest video sharing site; YouTube, which shows some videos from keywords "Ikatan Kimia"/"Chemical Bonding" within Indonesian language (Figure. 3) [16]. Most channels within Indonesian language show a coursework learning system, which is attempted for different purpose. They are not created for facilitating visual abstraction of submicroscopic world, yet, created as online video learning resembled to face-to-face learning (based on conventional class). When "Animasi Ikatan Kimia"/"Chemical Bonding Animation" was typed as keyword, we could only find few proper videos explaining Chemical process in the submicroscopic scale (Figure. 4). The rests are videos developed based on text and still picture from a presentation that is simply moved using a limited feature offered by simple application, such as Powtoon or VideoScribe. It needs to be considered that animation principal is animating (not just simply moving) the objects so it could be like the living objects, whilst it could not be done just by moving a set of still pictures.

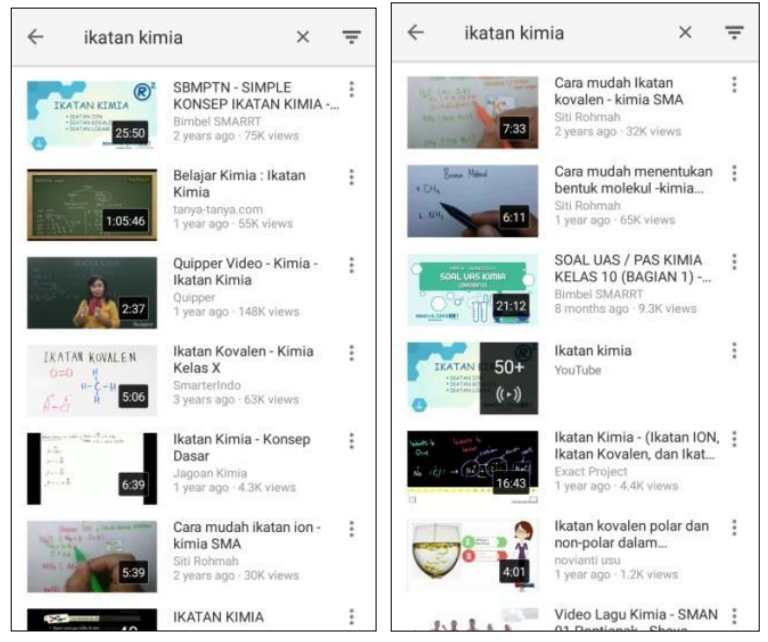

Figure. 3. Results from the keyword "Ikatan Kimia"

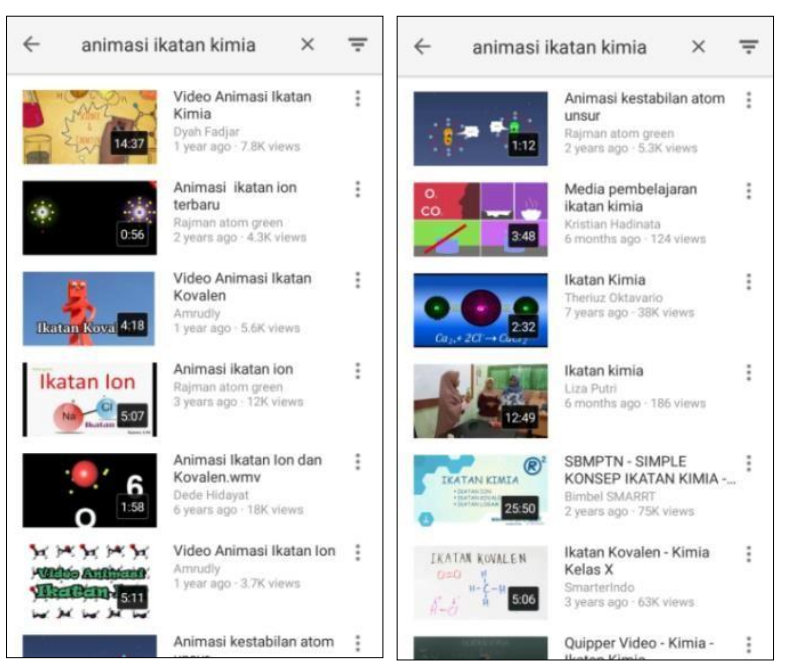

Figure. 4. Result from the keyword "Animasi Ikatan Kimia"

Survey from 15 teachers show that Chemical Bonding material has a middle level of difficulty (60\%) (9 of 15), the rests said that Chemical Bonding has a hard level of difficulty (40\%). No one said that this material is on the easy level. If it is be concluded, from the teachers' point of view, the difficulty of learning Chemistry is on its abstractive characteristic. It is proved by the students' difficulties, especially reasoning difficulty, and teachers' problem to ask the students to "imagine". Most teachers suggest solution to solve this problem by using the more "real" visualization for students offered by the use of animation (G2, G8, G12, G14, G15). The advantage of using animation is on its capability to show not only still picture, but also to facilitate moving and process in Chemistry which could be handled by live videos or direct practice.

\section{B. Alternative Solution: Development}

Here is a development done by researchers to build the product of Animation learning video of Chemistry. This development is an easy example to create the multimedia 
pro- duct which could be easily done by Chemistry teachers. It is because development design made by Alessi $\&$ Trollip was made from the research on beginner learning designer, as like teachers who do not have animation skill, but has capability to make a learning material design [17]. This development draft of animation video was made based on modification of development design which has been made by Alessi \& Trollip (2001), which can be seen in Table 1.

\section{The Importance of Storyboard}

Figure. 5 is an example of storyboard made by researcher to inquire Chemical Bonding material within its sub material which is about Atomic Stability of Noble Gasses Element and The Rule of Octet. The most important thing from multimedia development is on the storyboard. Storyboard is used to recheck the story and utilizes pencil sketches to review motion [10]. On the creating process of animation video, the most fundamental role of teacher is to be the learning material designer.

TABLE I

Chemistry Animation Video Development Draft

\begin{tabular}{|c|c|}
\hline \multicolumn{2}{|c|}{ Chemistry Animation Video Development Draft } \\
\hline & PLANNING \\
\hline Define the scope & $\begin{array}{l}\text { Target } \\
\text { Subject/Main Course } \\
\text { Level of competency which is needed } \\
\text { Development product }\end{array}$ \\
\hline $\begin{array}{l}\text { Identify learners } \\
\text { characteristics }\end{array}$ & $\begin{array}{l}\text { Age } \\
\text { Level of competency which is had } \\
\text { Analysis the need of multimedia }\end{array}$ \\
\hline Establish the constraints & $\begin{array}{l}\text { Tools } \\
\text { School's rules (related to the use of } \\
\text { gadget, etc.) }\end{array}$ \\
\hline $\begin{array}{l}\text { Produce a planning } \\
\text { document }\end{array}$ & $\begin{array}{l}\text { Target of finishing the multimedia project } \\
\text { (Time management) } \\
\text { Choose teamworkers (example: graphic } \\
\text { designer, animator) }\end{array}$ \\
\hline $\begin{array}{l}\text { Determine and collect } \\
\text { resources }\end{array}$ & Book/Publication/Syllable \\
\hline \multicolumn{2}{|r|}{ DESIGN } \\
\hline $\begin{array}{l}\text { Develop initial content } \\
\text { ideas }\end{array}$ & $\begin{array}{l}\text { Brainstorming \& eliminating video } \\
\text { ideas. }\end{array}$ \\
\hline $\begin{array}{l}\text { Prepare scripts \& Create } \\
\text { storyboards }\end{array}$ & $\begin{array}{l}\text { Making story board full with the script } \\
\text { which is made in two version } \\
\text { (Indonesian and English) for the need of } \\
\text { narator's audio recording and caption } \\
\text { attachment on YouTube) }\end{array}$ \\
\hline \multicolumn{2}{|r|}{ DEVELOPMENT } \\
\hline Create the graphics & $\begin{array}{l}\text { Storyboard visualization is done by } \\
\text { graphic designer. }\end{array}$ \\
\hline $\begin{array}{l}\text { Produce animation and } \\
\text { video }\end{array}$ & $\begin{array}{l}\text { Those visuals from graphic designers } \\
\text { would be transmitted to animator to } \\
\text { animate the visual objects and recording } \\
\text { narration sounds. }\end{array}$ \\
\hline
\end{tabular}

\section{ACKNOWLEDGMENT}

Researcher would like to thank to all those who helped this study research in especially to the teachers who joined the survey.

\section{REFERENCES}

[1] Elliot, S., Kratochwill, T., Cook, J., \& Travers, J. (2000). Educational Psychology: Effective Teaching, Effective Learning. New York: McGrawHill Companies

[2] Kemendikbud. (2017). Model Silabus Mata Pelajaran Sekolah Menengah Atas/Madrasah Aliyah (SMA/MA) Mata Pelajaran Kimia. Jakarta: Kemdikbud

[3] Sudarmo, U. (2009). Miskonsepsi Siswa SMA Terhadap Konsep-Konsep Kimia. Prosiding Seminar Nasional Kimia dan Pendidikan Kimia, (hal. 171-188). Surakarta

[4] Ardiansyah, Enawati, E., \& Lestari, I. (2014, September). Miskonsepsi Guru SMA Negeri Pada Materi Ikatan Kimia Menggunakan Certainty of Response Index (CRI). Jurnal Pendidikan dan Pembelajaran UNTAN

[5] Khabibah, E., Masykuri, M., \& Maridi. (2017). The Analysis of Generic Science Skills of High School Student. Advance in 
Social Science, Education and Humanities Research (ASSEHR). 158, hal. 251-256. Surakarta: Atlantis Press

[6] Seels, B., \& Richey, R. (1994). Teknologi Pembelajaran: Definisi dan Kawasannya. Jakarta: Unit Percetakan UNJ

[7] West, C., Farmer, J., \& Wolff, P. (1991). Instructional Design: Implications From Cognitive Science. Needham Heights, MA: Allyn and Bacon

[8] Gilbert, J.K. \& Boulter, C. (1998). Learning science through models and modeling. In B. Fraser \& K. Tobin (Eds.), International handbook of science education (pp. 53-66). Dordrecht, The Netherlands: Kluwer

[9] Johnstone, A. (1991). Why is science difficult to learn? Things are seldom what they seem. Journal of Computer Assisted Learning , 7, 75-83

[10] Musa, S., Ziatdinov, R., Griffiths, C. (2013). Introduction to computer animation and its possible educational applications. In M. Gallová, J. Gunĉaga, Z. Chanasová, M.M. Chovancová (Eds.), New Challenges in Education. Retrospection of history of education to the future in the interdiciplinary dialogue among didactics of various school subjects (1st ed., pp. 177-205). Ružomberok, Slovakia: VERBUM--vydavatelstvo Katolíckej university v Ružomberku

[11] Subotnick, S. (2003). Animation in the Home Digital Studio: Creation to Distribution. Burington, MA: Focal Press

[12] Wartomo. (2016). Peran Guru Dalam Pembeajaran Era Digital. Prosiding Temu Ilmiah Nasional Guru (TING) VIII, (pp. 265275).

[13] Sen, P. (2007, July 25). Tiny Finding that Opened New Frontier. Retrieved August 12, 2018, from BBC News: http://news.bbc.co.uk/2/hi/science/nature/6914175

[14] Ibda, F. (2015). Perkembangan Kognitif: Teori Jean Piaget. Intelektualita , 3 (3), 27-38.

[15] Bjuland, R. (2007). Adult Students' Reasoning in Geometry: Teaching Mathematics through Collaborative Problem Solving in Teacher Education. The Montana Mathematics Enthusiast, ISSN 1551-3440, Vol. 4, No. 1, 1-30

[16] YouTube. (n.d.). Retrieved August 12, 2018, from YouTube: http://m.youtube.com

[17] Alessi, S.M. \& Trollip, S.R. (2001). Multimedia for Learning: Methods and Development. Needham Heights, Massachusetts: Allyn \& Bacon 